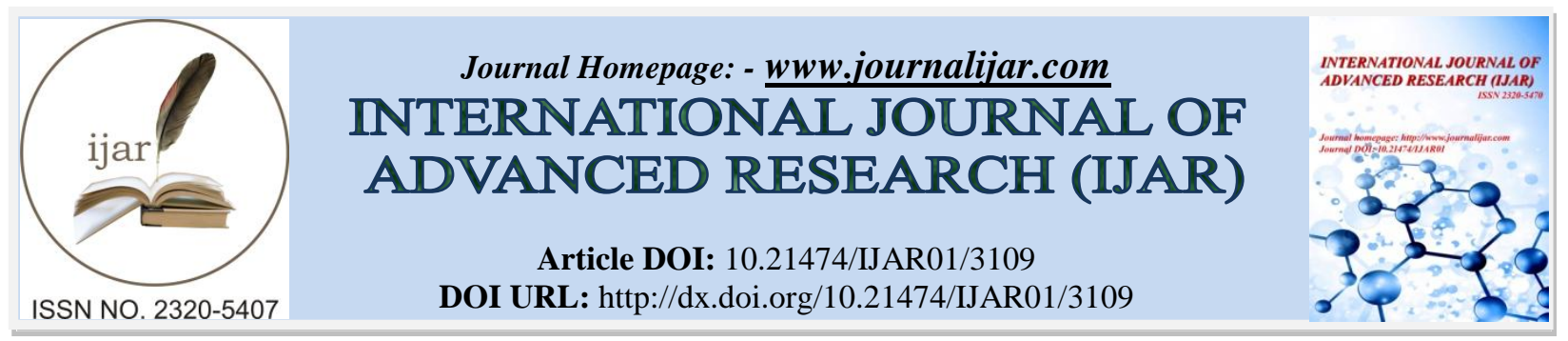

RESEARCH ARTICLE

\title{
DEVELOPMENT IN WOODS A SUSTAINABLE BUILDING.
}

\section{Hyeladzira Garba Mshelia, "Alhaji Kasir Lawan and Sadig Mala Mohammed.}

Dept. of Architecture Ramat polytechnic Maiduguri, Borno State.

\section{Manuscript Info}

Manuscript History

Received: 06 December 2016

Final Accepted: 02 January 2017

Published: February 2017

Key words:-

Wood, as a green building.

\begin{abstract}
Timber from plantation, growth and conversion in to Wood's design with the innovation of glulam, cross laminated timber (clt) makes it flexible, suitable for a wide range of building types and applications, both structural and aesthetic. Wood can be used in many types of buildings, from single-family homes to multi-storey condominiums and offices, schools, health facilities, recreational centres and public gathering areas. It is suitable not only as a finish material, bringing warmth and natural beauty to interior and exterior applications, but as a structural material, offering a cost-effective way to meet building code.
\end{abstract}

Copy Right, IJAR, 2017,. All rights reserved.

\section{Introduction:-}

\section{Wood:-}

Along with stone, clay and animal parts, wood was one of the first materials worked by early humans. Microware analysis of the Mousterian stone tools used by the Neanderthals show that many were used to work wood.

Wood is an organic, hygroscopic and anisotropic material. It's thermal, acoustic, electrical, mechanical, aesthetic, working, etc. But wood has some disadvantages too.

\section{General feature of a tree body:-}

As vascular plants, trees are organized into three major organs: the roots, the stems, and the leaves. The leaves are the principal photosynthetic organs of higher vascular plants. They are attached by a continuous vascular system to the rest of the plant so that free exchange of nutrients, water, and end products of photosynthesis (oxygen and carbohydrates in particular) can be carried to its various parts.

\section{Seasoning of Wood:-}

Seasoning is the process of removing the moisture content from wood to minimize structural problems when used in construction or to provide less smoke and more uniform combustion when used as firewood.

\section{Different Ways of Seasoning Wood:-}

i. Air Seasoning: The traditional method for drying wood, air seasoning is also the longest, taking six to nine months. To air season wood, stack logs or planks outside on pallets in such a manner that air can circulate vertically and horizontally through the timbers. The raised pallets also keep wood away from vegetation and damp ground. Plank and log ends are often wrapped or sealed to prevent excessive moisture loss through these areas. Protect the drying wood from the elements with an overhead canopy. 
ii. Kiln Seasoning: The most common and effective commercial process for drying wood is kiln seasoning, which accelerates the process of removing moisture through the use of external energy. Drying takes two days to one weekend, depending on the type of wood. Two methods, progressive and compartmental, are used for kiln seasoning. In a progressive kiln, timber enters at one end and travels on a trolley through chambers with different air conditions to progressive dry the wood. This method produces a constant flow of seasoned timber. Wood seasoned via the compartmental process remains in a single building where it is subjected to a program of varying conditions until the moisture content is removed. This process is used for hard-to-dry or expensive wood.

iii. Solar Kiln: This method combines the speed of kiln seasoning with the low energy of air drying. Solar kilns have single-thickness windows on the south side of the structure that work as collectors to trap the sun's energy. Heat collectors, made from black metal are attached near the top of the window sashes. Various methods force the heated air to circulate through the kiln to dry the wood. Some solar kilns have insulation to retain heat at night. This process takes approximately twice as long as traditional kiln seasoning. Because of its gentle nature, it is well suited to producing wood for furniture fabrication.

iv. Microwave Seasoning: Microwave seasoning uses pulsed energy directed into timbers to drive out moisture in a manner that will not cause seasoning degrade. This method also provides advantages such as high speed and high quality and is well suited for seasoning lumber, blocks, veneer, chips, paper and wood-based composite materials. Areas in the wood with the most moisture absorb the most energy resulting in even temperature during the drying process and uniform moisture content. These factors enhance quality and reduce timber checking and warping.

\section{Cross section of a tree truck:-}

i. Annual or growth rings: These indicate rapid growth resulting in thin walled fibre or smaller proportion of the denser wood.

ii. Bark: the outer layer, corklike and provides protection to the tree from knocks and other damage.

iii. Bast: the inner bark carries enriched sap from the leaves to the cells where growth takes place.

iv. Cambium: layer of living cells between the bast and the sapwood.

v. Crown: the branches and leaves that provide its typical summer shape.

vi. Heartwood: mature timber, no longer carries sap, the heart of the tree, and provides the strength of the tree.

vii. Medulla ray: (rays) food storage cells radiating from the medulla.

viii. Pith or medulla: the centre of the tree, soft and pithy especially in the branches.

ix. Sapwood: new growth, carries the raw sap up to the leaves.

$\mathbf{x}$. Trunk: main structure of the tree, produces the commercial timber.

xi. Root structure: Absorbs water and minerals from the soil.

\section{Hardwoods and Softwoods:-}

There are two main groups of timber producing trees used commercially; softwoods and hardwoods.

i. Softwoods: Softwoods are coniferous trees and the timber is not necessarily 'soft'. They are 'evergreen'. (The larch is an exception) Their general characteristics are: i. Straight, round but ii. Slender, tapering trunk.

ii. Hardwoods: Hardwood trees are broadleaf and generally deciduous. The general characteristics are: i. Stout base that scarcely tapers but divides into branches to form a wide, round crown. ii. The leaves are broad and may have single or multi lobes. Fig 2 shows three trunk.

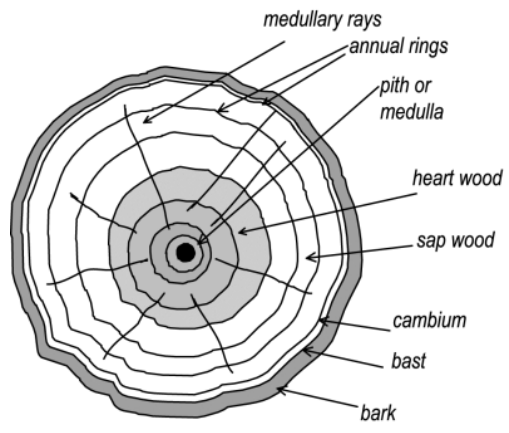

The tree trunk showing growth rings

Fig 1.3:- Represent tree trunk showing growth ring. Source: Geoff's Woodwork 


\section{Conversion of timber:-}

As soon as possible after felling the tree should be converted into usable timber. There are two main methods of converting timber: Through and through (or Plain or Crown sawn) which produces tangential boards and Quarter Sawn which produces radial boards.

Through and through produces mostly tangentially sawn timber and some quarter sawn stuff. (Fig 1.5) Tangential timber is the most economical to produce because of the relatively less repetitive production methods. It is used extensively in the building industry.

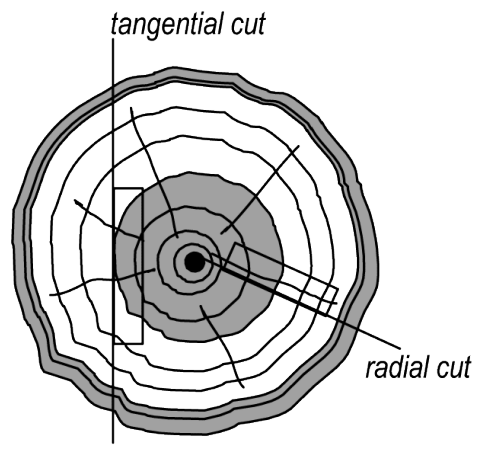

Fig 1.4:- through and through produces mostly tangentially. Source: Geoff's Woodwork.

There are other ways but they are all variations of tangential and radial cuts to obtain the best or most economical boards for the use it is to be put.

Tangential boards (crown, plain or flat sawn) are used extensively for beams and joists. See fig 1.5 below.

Radial boards (radial, figured or quarter sawn) are typically cut on 'the quarter' and produce a pattern of the medullary rays especially in quartered oak. See fig 1.5 below

Crown sawn is obtained by sawing tangentially to the annual rings. See fig 1.5 below.

Rift sawn is the cut which falls between crown and true quarter sawn. See fig 1.5 below

Quarter sawn boards are radial cut from the centre of the tree. See fig 1.5 below
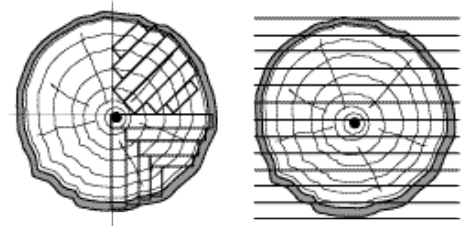

quartered conversion, showing through and through conversion.

2 different cuts (radial boards) (tangential and some radial boards.

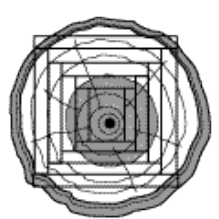

tangentlal cuts
(theart is boxed

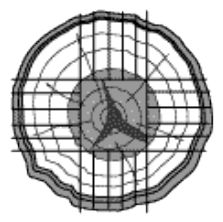

boxed heart

Fig 1.5:- Showing methods of conversion of a timber. Source: Geoff's Woodwork. 


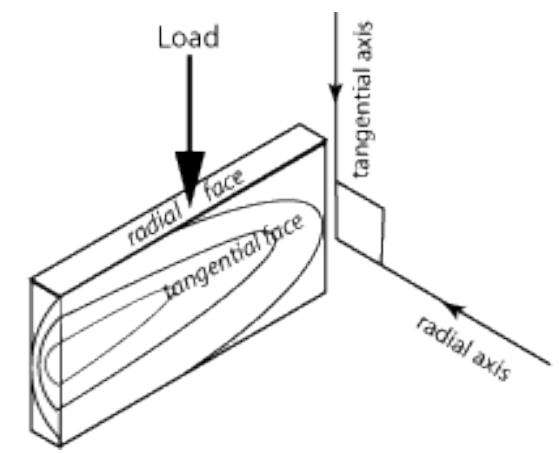

Fig 1.6:- shows method at which timber conversion has taken place. Source: Geoff's Woodwork Types of Woods Processed:-

\section{Hard Wood}

i. Oak: Oak is the most widely used hardwood. There are more than 60 species of oak grown in the U.S., which can be separated into two basic varieties; white and red. Properties: Oak is a heavy, strong, light colored hardwood. Uses: It is used to craft outdoor furniture and decorative carvings. Redwood burls have a "cluster of eyes" see fig 2.1.

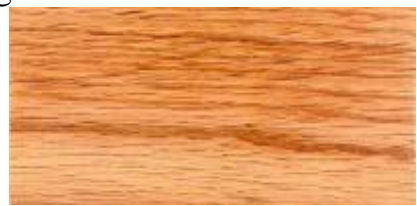

Fig 2.1 showing sample of oak wood. Source: hooved signs

ii. MAPLE: Properties: Maple is so hard and resistant to shocks that it is often used for bowling alley floors. Its diffuse evenly sized pores give the wood a fine texture and even grain. Burls, leaf figure, and birds-eye figures found in maple are used extensively for veneers. See fig 2.2 below. Uses: Maple is used extensively for colonial furniture, making.

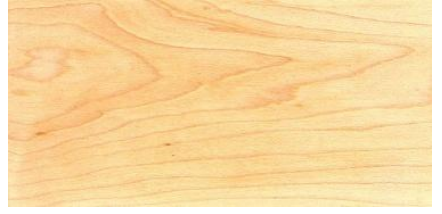

Fig 2.2 showing a sample of maple wood. Source: hooved signs

iii. MAHOGANY: is a tropical hardwood indigenous to South America, Central America and Africa. Properties: Mahogany is strong, with a uniform pore structure and poorly defined annual rings. It has a reddish - brown color and may display stripe, ribbon, broken stripe, rope, ripple, mottle, fiddleback or blister figures. Uses: Mahogany is used extensively in the crafting and furniture making see fig 2.3 below.

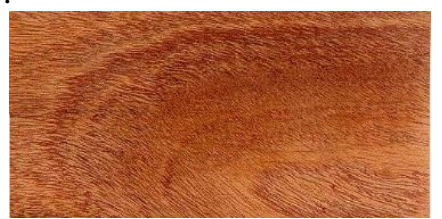

Fig 2.3 showing a sample of mahogany wood. Source: hooved signs

iv. CHERRY: Cherry is grown in the Eastern half of the U.S. It is sometimes called fruitwood. The term fruitwood is also used to describe a light brown finish on other woods. Properties: A moderately hard, strong, closed grain, light to red-brown wood, cherry resists warping and checking. It is easy to carve and polish. Uses: Cherry veneers and solids are used in a variety of styles. See fig 2.4 below. 


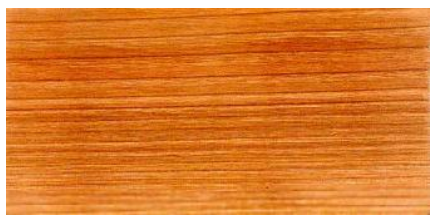

Fig 2.4 showing a sample of cherry wood. Source: hooved signs

v. WALNUT: Walnut is one of the most versatile and popular cabinet making woods. It grows in Europe, America and Asia. There are many different varieties. Properties: Walnut is strong, hard and durable. Uses: used in all types of fine cabinet work. See fig 2.5 below

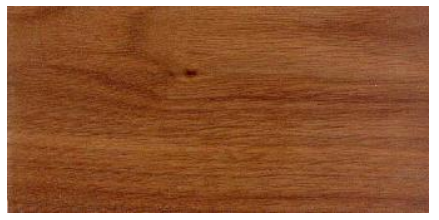

fig 2.5 showing a sample of walnut wood. Source: hooved signs

vi. ROSEWOOD: Very hard and has a dark reddish brown color. It is fragrant and close grained. It is hard to work and takes high polish. Used in musical instruments, piano cases, tool handles, art projects, veneers and furniture. See fig 2.6 below.

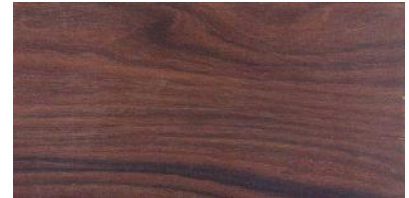

Fig 2.6 showing a sample of rose wood. Source: hooved signs

vii. TEAK: True teak is indigenous to Southeast Asia, but similar wood species also grow in Africa. Properties \& Uses: Teak is a yellow to dark brown hardwood which is extremely heavy, strong and durable. See fig 2.7 below

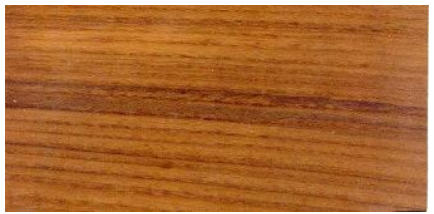

Fig 2.7 showing a sample of rose wood. Source: hooved signs

\section{SOFTWOODS}

i. HICKORY: There are 15 species of hickory in the eastern United States, eight of which are commercially important. Properties: Hickory is one of the heaviest and hardest wood. See fig 2.8

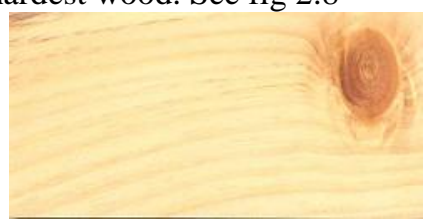

Fig 2.8 showing a sample of hickory wood. Source: hooved signs

iv. CEDAR: Several species of cedar grow in the southern United States, Central and South America. Properties \& Uses: Cedar is a knotty softwood which has a red-brown color with light streaks. Simple cases and storage closets are also constructed from this light, brittle wood. See fig 2.12 below

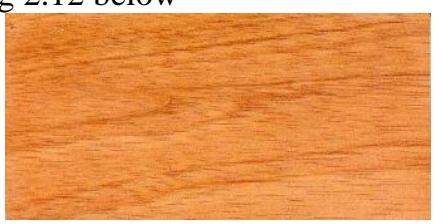

Fig 2.13 showing a sample of cedar wood. Source: hooved signs 
v. REDWOOD: Indigenous to the Pacific United States. Properties \& Uses: It is used to craft outdoor furniture and decorative carvings. Redwood burls have a "cluster of eyes" figure. See fig 2.14 below

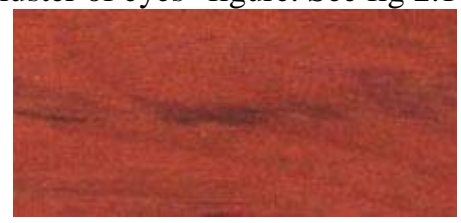

Fig 2.14 showing a sample of red wood. Source: hooved signs

vi. BIRCH: There are many species of birch. Properties \& Uses: Birch is a hard, heavy, close grained hardwood with a light brown or reddish colour. See fig 2.15 below.

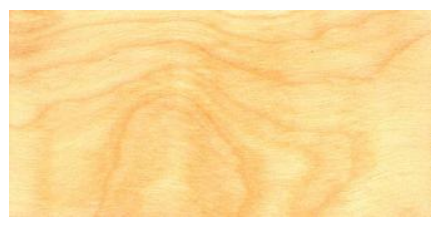

Fig 2.16 showing a sample of birch wood. Source: hooved signs

vii. BEECH: The American beech is a single species which grows in the eastern half of the United States. Properties \& Uses: Beech is a hard, strong, heavy wood with tiny pores and large conspicuous medullary rays, similar in appearance to maple. Uses: used for frames, a variety of bent and turned parts. See fig 2.17 below.

Fig 2.17 showing a sample of beech wood. Source: hooved signs

viii. IRCH: There are many species of birch. The yellow birch is the most commercially important. European birch is fine grained, rare and expensive. See fig 2.18 below

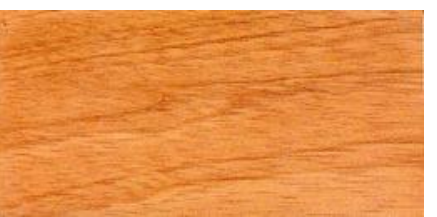

Fig 2.18 showing a sample of irch wood. Source: hooved signs

\section{Application of Wood as a Building Material:-}

i. Quick to Build: Saves Money: Some wooden home manufacturers can construct a $100 \mathrm{~m}^{2}$ wooden house, on site within 7 days. When compared with brick, stone or concrete, wood constructions certainly do save time, and inherently with that come savings in labour. Wood-framed houses enable easy modifications during and after the building process and it's because of the ease, versatility and cost effectiveness which makes it such a popular and inexpensive choice. Insulated concrete form homes (ICF) can be costly, troublesome and time consuming to alter post builds.

\section{ii. Environmentally friendly}

Houses made from trees are sustainable, renewable and environmentally friendly. Did you know that wooden structures absorb and store atmospheric $\mathrm{CO} 2$, even taking into account haulage, is carbon neutral (in fact, it's the only carbon neutral construction material). Mature trees actually use absorb less carbon than younger, faster growing trees, therefore it could be beneficial in the battle on climate change to cut the older trees, use them in construction and plant new carbon munching trees in their place.

iii. Mechanical Properties \& Working Properties: Wood, although light has a remarkably high tensile strength. Let's take wood which has a tensile strength of $0,6 / \mathrm{cm} 3$ and the specific gravity is $100 \mathrm{~N} / \mathrm{mm} 2$, as well as steel which has a tensile strength of $7,89 / \mathrm{cm} 3$ and the specific gravity is $500 \mathrm{~N} / \mathrm{mm} 2$. 
When it comes to how workable wood is, few things can surpass it. Wood can be whittled in beautiful and creative ways, which can make for almost magical designs. The accuracy and finish that can be achieved with wood can help carve an ordinary design into something extraordinary. Further to that, wood is fairly easy to maintain and to repair.

iv. Safe, Light, Sturdy \& Durable: One of the many reasons why wood is still used today, despite huge strides in engineering excellence, is its durability weight and safety. Wood has a little bit of give in it which means it can bend slightly, which is a property which bricks don't have. Therefore, if the foundations shift slightly, the wooden home can flex and move with the change rather than crack. Even the smallest shift in the foundations of a brick house will case cracks to appear in the mortar (not a good look). They are cheaper to rebuild if destroyed by a hurricane.

v. Wood a Versatile and Innovative Way to Build: Wood is the building material of the future-versatile, beautiful, and durable. Wood is being used in new and exciting ways to build taller multi-storey structures. Large public buildings like arenas, gymnasiums, office buildings, and apartment complexes can be constructed from wood. New wood products, like Cross Laminated Timber and Glulam, are changing the face of construction, allowing taller wood buildings.

vi. Building Wooden Skyscrapers: The use of Cross Laminated Timber (CLT) is opening up new possibilities for using wood in non-residential, multi-storey buildings. Developed in Europe in the 1990s, CLT is an engineered wood panel typically consisting of three, five or seven layers of dimensional lumber. Kiln-dried boards are layered perpendicular to one another and then glued. This cross lamination provides dimensional stability, strength and rigidity. A recent study conducted on behalf of the Canadian Wood Council concluded that CLT is feasible for 12 stories or more.

In November 2012, the International Code Council approved a code change to expand the use of cross laminated timber through the building code's heavy timber construction classification.

vii. Providing Strong and Beautiful Structure: Glulam makes efficient use of wood by bonding smaller pieces of dimension lumber together to form larger beams and columns. Used in place of concrete for beams and columns, Glulam can bring innovation and beauty to both commercial and residential buildings.

\section{Conclusion:-}

Wood is the building material of the future. New wood products, like Cross Laminated Timber and Glulam, are changing the face of construction, allowing taller wood buildings.

\section{References:-}

1. David, D. (2014) in Freshome's Very Best http://freshome.com. timber-architecture-9- Benefits-wood-baseddesigns/\#ixzz4Y9GMfgWU. Retrieved November 2015.

2. Smith, R.C. \& Andres C.K., (1986) material for construction fourth edition. McGraw-hill International Editions, Civil Engineering series.

3. Kodgire, V.D., (2015) Material Science and Metallurgy for Engineers. ISBN NO: 81-86314-00-8

4. Everest publishing house

5. http://www.rethinkwood.com/wood-versatile/new-and-innovative-wood-uses. Retrieved November

6. 2015 .

7. https://www.forestfoundation.org/wood--a-versatile-and-innovative-way-to-build. Retrieved November

8. 2015 .

9. Geoffs Woodwork www.geoffswoodwork.co.uk. Retrieved November 2015. 